Кузнецов

Евгений Николаевич, доцент кафедры гражданского процесса

Уральского государственного юридического университета, кандидат юридических наук corben2002वmail.ru
DOI: 10.18572/1812-383X-2020-12-3-8

\section{Гражданские процессуальные правоотношения: вопросы теории}

В статье рассматриваются теоретические аспекты гражданских процессуальных правоотношений. Анализируются советские и российские подходы к сущности процессуальных правоотношений. Выделяются особенности научного анализа гражданских процессуальных правоотношений в немецкой доктрине. Определяются состав, объект, субъекты и содержание гражданских процессуальных правоотношений.

Ключевые слова: гражданский процесс, арбитражный процесс, правоотношение, судебная защита, гражданское процессуальное правоотношение.

\title{
Civil Procedure Relations: Issues of Theory
}

Kuznetsov Evgeniy N.

Associate Professor of the Department of Civil Procedure of the Ural State Law University

$\mathrm{PhD}$ (Law)

The article deals with the theoretical aspects of civil procedural legal relations. The article analyzes the Soviet and Russian approaches to the essence of procedural legal relations, the features of the scientific analysis of civil procedural legal relations in the German doctrine. The composition, object, subjects and content of civil procedural legal relations are determined.

Keywords: civil procedure, arbitration procedure, legal relationship, judicial protection, civil procedural legal relationship. 